\title{
Serological Characterization of Major Viruses infecting Strawberry in India
}

\author{
Abhilasha Sharma* and Anil Handa \\ Plant Virology Laboratory, Dr. Y S Parmar University of Horticulture and Forestry, Nauni, \\ Solan, (HP), India \\ *Corresponding author
}

\section{A B S T R A C T}

Keywords

Serological

Characterization,

Strawberry, DAS-ELISA

Article Info

Accepted:

26 April 2018

Available Online:

10 May 2018
Strawberry (Fragaria x ananassa Duchesne) is one of the most important commercial plants representing Rosaceae family. Like other fruit crops, strawberry is also known to be susceptible to diseases caused by fungi, bacteria and viruses. Since strawberry is propagated through runners year after year, the mother stocks often get infected with viruses pass on these viruses to the next progenies. Reports indicate that more than 30 viruses and phytoplasmas infect strawberry naturally. The most important viruses are strawberry latent ringspot virus (SLRSV), tobacco ringspot virus (TRSV), raspberry ringspot virus (RRSV), tobacco streak virus (TSV) and strawberry Mild yellow edge virus (SMYEV). A detailed investigation was conducted to characterize the major viruses infecting strawberry on serological basis using both Direct Antigen Coating (DAC) and Double Antibody Sandwich (DAS) forms of ELISA. The studies found DAS-ELISA to be more precise than DAC-ELISA for serological characterization of strawberry viruses.

\section{Introduction}

Strawberry is an important fruit crop of India and its commercial production is possible in temperate and sub-tropical areas of the country. It is one of the most favourite fruits of the temperate world. Strawberry cultivation is gaining more popularity in the plains of Punjab and northern states due to higher yields resulting in lucrative returns. In India, total area and production under strawberry is 1000 ha and 5000MT, respectively and in Himachal Pradesh, strawberry is cultivated over an area of 55 ha with a production of 559MT (NHB, 2017). There are reports indicating that about 30 viruses infect strawberry crop under natural condition. It can lead up to 30 percent yield reduction and losses can be up to 80percent in mixed infections with other viruses (Thompson and Jelkmann, 2003; Martin and Tzanetakis, 2006). A detailed and critical study of the symptoms observed on strawberry plants infected with viruses revealed a combination of wide range of symptoms extending from mild mottle to cupping of leaves with majority of the plants exhibiting puckering, necrotic rings, ringspots, marginal necrosis, reddening of leaves, oak leaf pattern, leaf deformation and small sized misshapen fruits (Fig. 1-9). Virus diseases are a major limiting factor in the production of certified virus- free planting material of strawberry. 
Serological characterization of viruses infecting strawberry will help in the production of virus indexed planting material of strawberry which in turn will go a long way for developing a sound certification programme in this commercially important crop.

\section{Materials and Methods}

\section{Planting material}

Leaves from strawberry cv. Chandler with virus like symptoms were collected during the cropping season of 2017 from HRTS \& KVK kandaghat, Solan and IARI Regional Station Dhanda Farm, Shimla.

\section{ELISA detection}

DAC (Direct Antigen Coating) and DAS (Double Antibody Sandwich) forms of ELISA were used for the detection of viruses in the test samples. The procedure for conducting DAC-ELISA and DAS-ELISA is presented in the following paragraphs.

\section{DAC-ELISA}

In case of DAC-ELISA, the modified procedure given by Handa and Bhardwaj (1994) was followed. Wells of the microtitre plate (NUNC maxisorp certified micro plates) except those of the top and bottom rows and rows on the extreme left and right, were filled with $100 \mu \mathrm{l}$ aliquots of infected sap (each sample in duplicate) diluted in $1 \mathrm{X}$ extraction buffer (1: 10 ratio $\mathrm{w} / \mathrm{v}$ ) besides positive and negative control wells. The plate was incubated in humid box for 2 hours at $37^{\circ} \mathrm{C}$. The contents of the plate were removed by shaking out the plate over the washbasin. The wells were filled with $1 \mathrm{X}$ PBS-Tween and kept for 2 minutes with gentle shaking. The plate was emptied and filled again with PBSTween. The washing was repeated three times. The coating antibodies were diluted in $1 \mathrm{X}$ coating buffer (1:500 ratio v/v). The wells were filled with $100 \mu 1$ aliquots of antibodies. The plates were incubated for 2 hours at $37^{\circ} \mathrm{C}$. The washing steps were repeated as mentioned above. The alkaline phosphatase (ALP) conjugated goat-antirabbit $\operatorname{IgG}$ were filled in each well with $100 \mu$ l aliquots after diluting it in $1 \mathrm{X}$ ECI (enzyme conjugated immunoglobin) buffer at a ratio of 1: 200 $(\mathrm{v} / \mathrm{v})$. The plates were incubated in humid box for 90 minutes at $37^{\circ} \mathrm{C}$. Washing was done as mentioned above. The p-nitrophenyl phosphate (pNPP) substrate was dissolved in $1 \mathrm{X}$ substrate buffer by dissolving $5 \mathrm{mg}$ pNPP tablet in $5 \mathrm{ml}$ of $1 \mathrm{X}$ substrate buffer. Each well was filled with $100 \mu \mathrm{l}$ aliquots of substrate. The plates were kept in humid box in the dark condition at room temperature until a yellow colour was clearly visible in the positive control (usually between 30 minutes to 60 minutes). If desired, the reaction was stopped by adding $50 \mu \mathrm{l}$ of $3 \mathrm{M} \mathrm{NaOH}$ to each well. The results were assessed by measurement of the absorbance value of the hydrolysed substrate (p-nitrophenyl) at $405 \mathrm{~nm}$ wavelength in a microtitre plate reader (Micro Scan MS 5608A, Electronics Corporation of India Limited, Hyderabad). The results of ELISA for the detection were interpreted as per Dijkstra and Jager (1998) as samples were considered infected when their absorbance values $\left(\mathrm{A}_{405 \mathrm{~nm}}\right)$ exceeded two times the mean value of respective healthy control samples.

\section{DAS-ELISA}

The protocol given by Clark and Adams (1977) was followed for conducting DASELISA tests. Wells of the microtitre plate (NUNC maxisorp certified microplates) except those of the top and bottom rows and rows on the extreme left and right, were filled with $100 \mu \mathrm{l}$ aliquots of coating antibodies diluted in $1 \mathrm{X}$ coating buffer (1:500 ratio v/v). The plate was incubated in humid box for 4 hours at $37^{\circ} \mathrm{C}$. The coating antibody suspension was removed by shaking out the 
plate over the wash basin. The wells were filled with $1 \mathrm{X}$ PBS-Tween and kept for 2 minutes with gentle shaking. The plate was emptied and filled again with PBS-Tween. The washing was repeated three times. The test samples were ground in $1 \mathrm{X}$ extraction buffer (1:10 ratio w/v). All coated wells were filled with $100 \mu \mathrm{l}$ aliquots of test sample (each sample in duplicate) besides positive and negative control wells. The plates were incubated in humid box overnight at $4 \pm 1{ }^{\circ} \mathrm{C}$. The washing steps were repeated as mentioned above. The alkaline phosphatase (ALP) conjugate antibodies were filled in each well with $100 \mu \mathrm{l}$ aliquots after diluting it in $1 \mathrm{X}$ conjugate buffer at a ratio of 1:500 (v/v). The plate was incubated in humid box for 2 hours at $37^{\circ} \mathrm{C}$. The washing was done as mentioned above. The p-nitrophenyl phosphate (pNPP) substrate was dissolved in $1 \mathrm{X}$ substrate buffer. Each well was filled with $100 \mu \mathrm{l}$ aliquots of substrate. The plates were kept in humid box in dark condition at room temperature until a yellow colour was clearly visible in the positive control (usually between 30 to 60 minutes). If desired, the reaction was stopped by adding $50 \mu \mathrm{l}$ of $3 \mathrm{M} \mathrm{NaOH}$ to each well. The results were assessed in the same manner as for DAC-ELISA.

\section{Results and Discussion}

In order to characterize the viruses infecting strawberry on serological basis, DAC-ELISA was performed initially to broadly identify the virus groups to which the causal viruses belong.

For this purpose, antibodies against viruses representing each of the three genera namely Nepovirus, Ilarvirus and Potexvirus were used. It is evident from the data in Table 1 that TRSV (a member of the genus Nepovirus), TSV (a member of Ilarvirus) and SMYEV (a member of Potexvirus) were found to be prevalent in all the isolates collected from the two locations, Kandaghat and Dhanda.

These results were further confirmed in DASELISA using antibodies against these three viruses in addition to SLRSV and RRSV both members of the genus Nepovirus. Strawberry virus isolates collected from Kandaghat had the highest OD value for all the virus genera for nepoviruses 1.182, Ilarviruses 1.736 and for potexviruses 1.386 as compared to the virus isolates collected from Dhanda.

A number of workers have found DACELISA to be very efficient in the detection of nepoviruses, ilarviruses and potexviruses in different crops (Fromme et al., 1927; Abtahi and Habibi, 2008; Vemana and Jain, 2011; Sharma et al., 2018; Hepp and Martin, 1991; Conci et al., 2009; EPPOICABI, 1996). DACELISA results in the present study are in line with these findings and have also proved to be very efficient as it detected all three viruses successfully.

Table.1 DAC-ELISA detection of strawberry viruses

\begin{tabular}{ll|l|l|l|l|} 
Genera & Antibody & Locality & \multicolumn{3}{|c|}{ Mean OD at 405nm } \\
\cline { 3 - 6 } Nepovirus & TRSV & Kandaghat & $1.182(+)$ & $0.797(+)$ & $0.070(-)$ \\
\hline \multirow{2}{*}{ Ilarvirus } & \multirow{2}{*}{ TSV } & Dhanda & $0.602(+)$ & $0.574(+)$ & $0.058(-)$ \\
\hline Potexvirus & \multirow{2}{*}{ SMYEV } & Kandaghat & $1.736(+)$ & $1.236(+)$ & $0.123(-)$ \\
& & Dhanda & $1.227(+)$ & $0.755(+)$ & $0.131(-)$ \\
\hline & Kandaghat & $1.386(+)$ & $0.912(+)$ & $0.095(-)$ \\
\hline
\end{tabular}


Table.2 DAS-ELISA detection of strawberry viruses

\begin{tabular}{|l|l|l|l|l|}
\hline \multirow{2}{*}{ Antibody } & \multicolumn{3}{|c|}{ Mean OD at 405nm } \\
\cline { 2 - 5 } & \multicolumn{1}{|c|}{ Test sample } & Positive control & Negative control \\
\hline SLRSV & Kandaghat & $0.405(+)$ & $0.344(+)$ & $0.048(-)$ \\
\hline & Dhanda & $0.449(+)$ & $0.275(+)$ & $0.112(-)$ \\
\hline & Nauni & $0.206(+)$ & $0.236(+)$ & $0.056(-)$ \\
\hline TRSV & Kandaghat & $0.403(+)$ & $0.341(+)$ & $0.061(-)$ \\
\hline & Dhanda & $0.449(+)$ & $0.459(+)$ & $0.262(-)$ \\
\hline & Nauni & $0.244(+)$ & $0.170(+)$ & $0.047(-)$ \\
\hline RRSV & Kandaghat & $0.340(+)$ & $0.328(+)$ & $0.069(-)$ \\
\hline & Dhanda & $0.575(+)$ & $0.675(+)$ & $0.046(-)$ \\
\hline & Nauni & $0.398(-)$ & $0.417(+)$ & $0.047(-)$ \\
\hline Kandaghat & $1.078(+)$ & $1.109(+)$ & $0.332(-)$ \\
\hline & Dhanda & $0.690(+)$ & $0.576(+)$ & $0.223(-)$ \\
\hline & Nauni & $0.206(+)$ & $0.262(+)$ & $0.056(-)$ \\
\hline Kandaghat & $0.378(+)$ & $0.375(+)$ & $0.035(-)$ \\
\hline & Dhanda & $0.217(-)$ & $0.445(+)$ & $0.117(-)$ \\
\hline & Nauni & $0.147(+)$ & $0.153(+)$ & $0.034(-)$ \\
\hline
\end{tabular}

\section{FIG.1 Deformed fruits from infected plants}

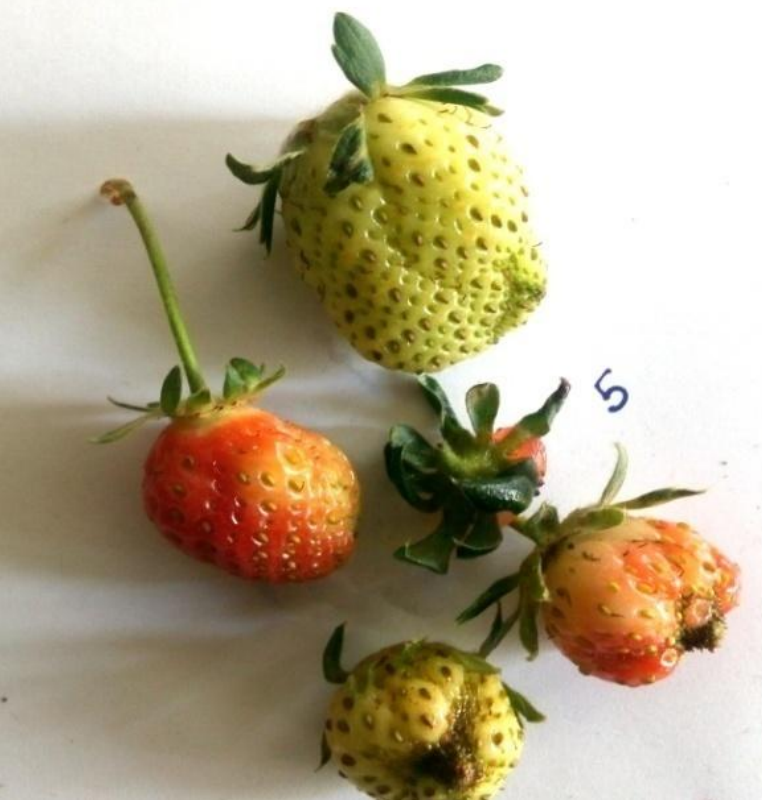




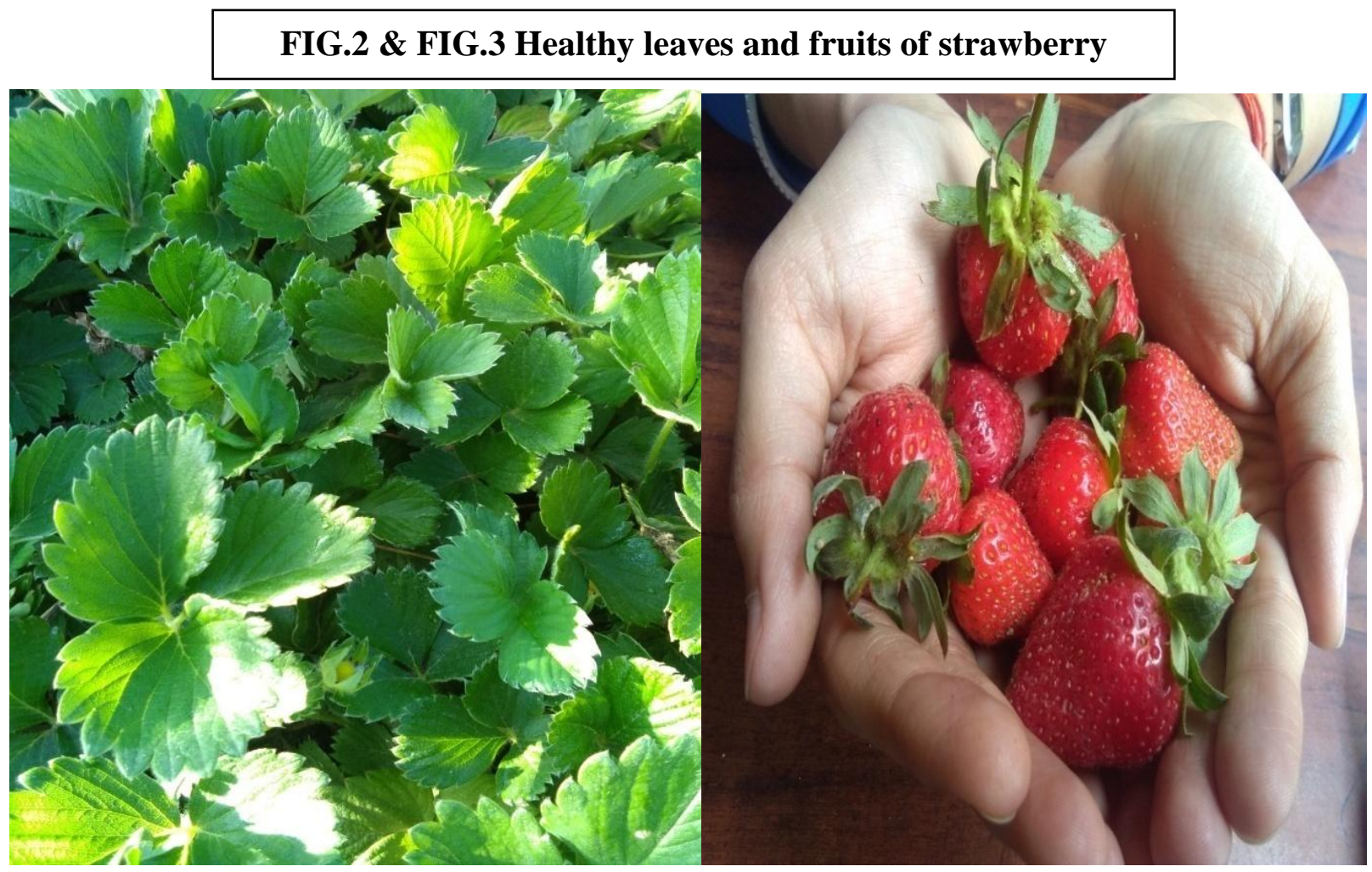

FIG.4 Severe leaf deformity

FIG.5 Leaf crinkling and marginal necrosis

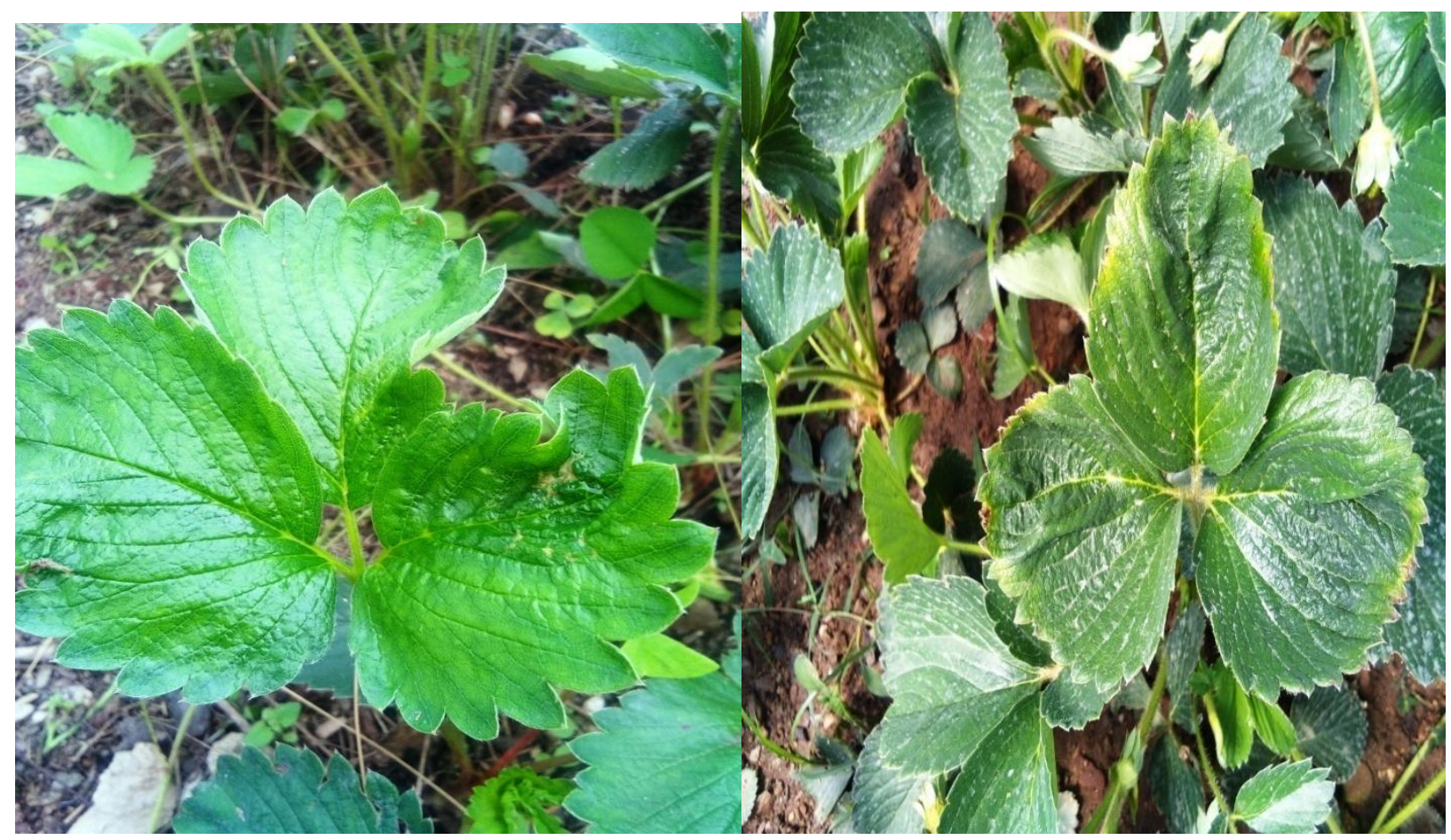


FIG. 6 Necrotic ringspots

FIG.7 Savoying

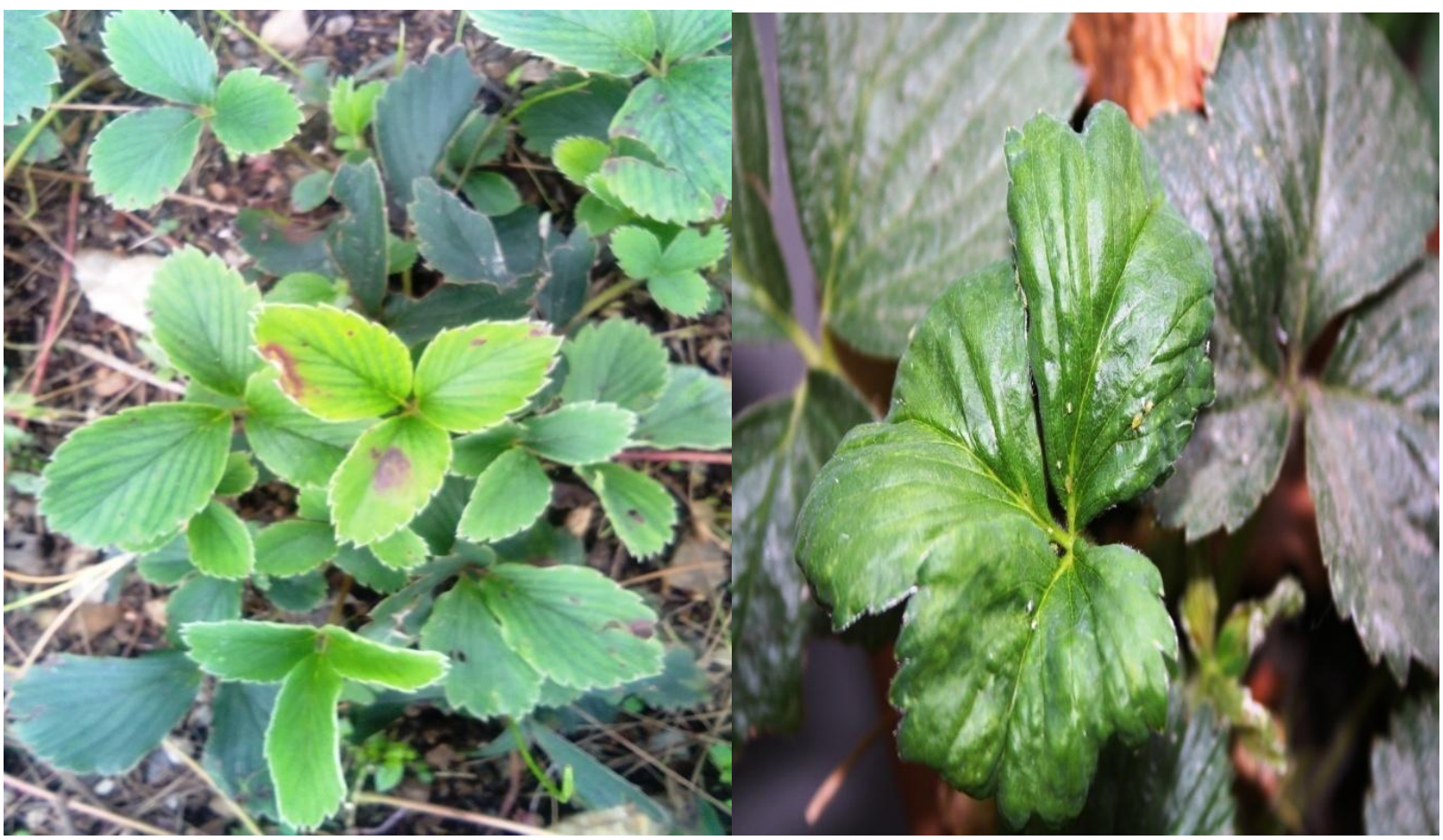

FIG.8 Cupping and leaf deformation

FIG.9 Typical ringspots

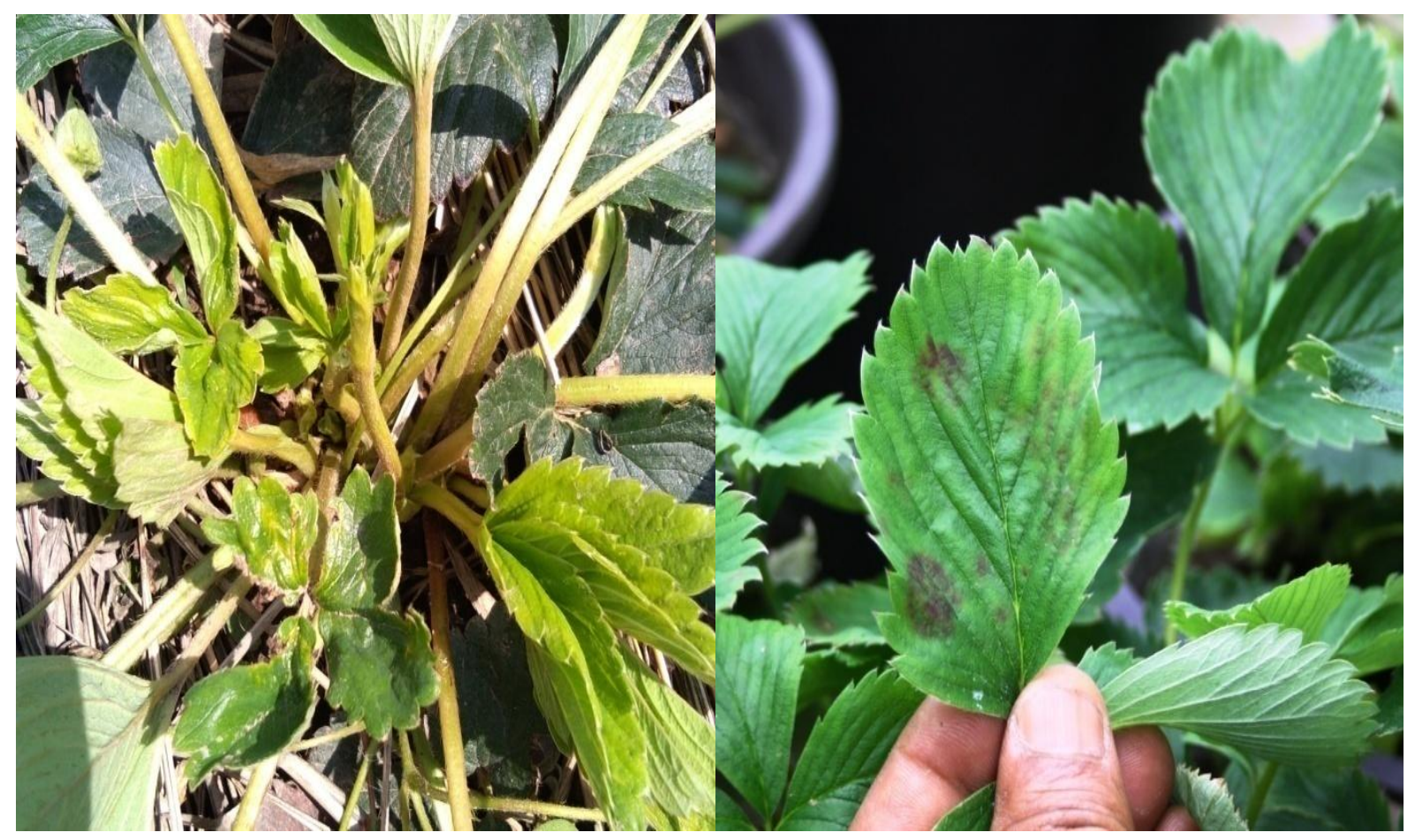


For more accurate and specific detection of strawberry viruses, three viruses namely SLRSV, TRSV and RRSV representing the genus nepovirus were used for DAS-ELISA based serological characterization of the causal viruses. Additionally, antibodies against TSV (Ilarvirus) and SMYEV (Potexvirus) were also used for exact identification of the virus. Data set out in Table 2 indicate the presence of all the viruses for which antibodies were used for DASELISA based characterization in the virus isolates collected from the all localities except for the SMYEV (Potexvirus) at Dhanda where concentration of the virus was found to be below detectable limits. DAS-ELISA was thus considered to be an effective and efficient method for the detection of strawberry viruses.

A number of workers have found DASELISA to be very efficient in the detection of nepoviruses, ilarviruses and potexviruses in different crops (Sharma et al., 2018; Bargen et al., 2015; Tang et al., 2013). DAS-ELISA results in the present study are in line with these findings and have also proved to be very efficient as it detected all three viruses successfully.

\section{Acknowledgments}

The authors sincerely acknowledge the Ministry of Agriculture, Government of India for funding the RKVY research project under which this research work was carried out. The authors also acknowledge the help received from Principal Scientist and Head, KVK Kandaghat and IARI Regional Station, Shimla for providing the planting material and research facilities.

\section{References}

Abtahi, F.S. and Habibi M.K. 2008. Host range and some characterization of
Tobacco Streak Virus isolated from lettuce in Iran. African Journal of Biotechnology., 7:4260-4264

Anonymous, 2017. $2^{\text {nd }}$ www.hpagrisnet. gov.in/horticulture.

Bargen, S.V., Demiral, R. and Buttner C. 2015. First Detection of Raspberry Ringspot Virus in Mosaic Diseased Hybrid Roses in Germany. New Disease Reports., 32:18.

Clark, M.F. and Adams A.N. 1977. Characteristics of the microplate method of enzyme linked immunosorbent assay for the detection of plant viruses. Journal of General Virology., 34:475-483.

Conci, V.C., Torrico, A.K., Cafrune, E. and Kirschbaum, B.S. 2009. First Report of Strawberry Mild Yellow Edge Virus in Argentina. Acta Horticulturae., 842(842): 303-306.

Dijksha, J. and Jager C.D. 1998: Practical Plant Virology. Springer., Lab Manuals. $145 \mathrm{p}$.

EPPO/CABI, 1996. Strawberry veinbanding caulimovirus. In: Quarantine pests for Europe. 2nd edition (Ed. by Smith, I.M.; McNamara, D.G.; Scott, P.R.; Holderness, M.). CAB International, Wallingford, UK.

Handa, A. and Bhardwaj S.V.1994. Comparative study of the use of alkaline phosphatase and penicillinase based direct antigen coating ELISA for the detection of a potyvirus from faba bean. FABIS., 34: 36-38.

Hepp, R.F. and Martin R.R., 1991. Occurrence of strawberry mild yellowedge associated virus in wild Fragaria chiloensis in South America. Acta Horticulturae., No. 308, 57-60.

Martin, R.R. and Tzanetakis L.E. 2006. Chracterization and Recent Advances in Detection of Strawberry Viruses. Plant Diseases., 90:384-396. 
Sharma, A., Handa, A., Kapoor, S., Watpade, S., Gupta, B and Verma P., 2018 Viruses of strawberry and production of virus free planting material- A critical review. International Journal of Science, Environment and Technology., 7: 521545.

Tang, J., Ward, L.I. and Clover G.R.G. 2013. The diversity of strawberry latent ringspot virus in New Zealand. Plant Disease., 97:662-667.

Thompson, J.R. and Jelkmann W. 2003. The detection and variation of Strawberry mottle virus. Plant Disease 87: 385-390. Vemana, K. and Jain R.K.2011. New experimental hosts of Tobacco streak virus and absence of true seed transmission in leguminous hosts. Indian Journal of Virology 21: 117-127.

\section{How to cite this article:}

Abhilasha Sharma and Anil Handa. 2018. Serological Characterization of Major Viruses infecting Strawberry in India. Int.J.Curr.Microbiol.App.Sci. 7(05): 3674-3681. doi: https://doi.org/10.20546/ijcmas.2018.705.424 